\title{
Analysis of the Influences of Prudential Sharia and Life Protection towards the Customer Welfare: Sharia Prudential Insurance in South Sulawesi
}

\author{
Mahsyar \\ Institut Agama Islam Negeri Parepare \\ mahsyarnurhayati@gmail.com
}

\author{
St. Nurhayati \\ Institut Agama Islam Negeri Parepare \\ nurhayatimahsyar@gmail.com
}

\author{
Nun Maziyyah binti Mahsyar \\ Universitas Muhammadiyah Yogyakarta \\ nunmaziyyah98@gmail.com
}

\begin{abstract}
Nowadays there are many insurance companies in the Indonesia segregated from all over the country. The insurance company in Indonesia has two systems and those are conventional insurance and sharia insurance. Indonesia is not an Islamic country but dominantly inhabited by the Muslim people whom are approximately $82 \%$ of Muslim population. Therefore, this research will focus on sharia insurance in Indonesia which has been growing quickly and giving a lot of advantages to the customers who obtain benefit and build the system of sharia insurance itself. The purpose of this research is to explain the welfare received by the society, which join with the sharia insurance in terms of benefits. This research was done by the quantitative approach by distributing the questionnaires to the customers as informants of the research, particularly in South Sulawesi areas to analyze the influences of prudential sharia and life protection towards customer welfare.
\end{abstract}

Keywords: sharia, prudential, insurance, costumer welfare, life protection

\section{INTRODUCTION}

Insurance is a need for the society that acts as a tool of protection in life. Literally, assurantie (Dutch) or insurance (English) means a company which guarantees the loss that happened. According to the Republic Act No. 2/1992 about insurance; it is stated that insurance is a mutual agreement between two or more parties, in which the insurer is bond to the agreement with the insured due to deprivation, damage, or loss of expected profit, or legal responsibilities to the third parties. The insured might be suffered due to uncertain risky events, or payments caused by death. Insurance in Indonesia is divided into two: conventional and sharia. Conventional insurance is based on an exchange of premium payments now for future indemnities in case of specified events. Such an exchange (sale) contract would not be valid under Sharia law due to the uncertainty (gharar) of the value of the future indemnities," the difference between them is studied in three parts that are the fundamental concept, risk management, and principal differences [1], [2].

According to those differences, it shows a different path between conventional and sharia insurance. One of the companies that has both conventional and sharia insurance is Prudential. According to National Sharia Councils (Dewan Shariah Nasional), sharia insurance (ta'amin, takaful or tadhamun) is an effort to protect and to help each other among some people/parties, through investment in form of assets and/or tabarru' which, according to sharia, gives return patterns to face certain risks through akad (bond), in which every product of sharia insurance is based on the regulations and sharia laws. The relation between companies-customers in sharia insurance in terms of the contract (akad); the company is the responsible party (wakil) [3]. Meanwhile, in conventional insurance, the company is the full owner of the insurance fund, so the full profit goes to the company. In contrast, with sharia insurance, the profit is also customers' profit.

According to Sula, in the practice of conventional insurance, the insurance premium is claimed as the profit, despite it has been paid or not. [4]. Meanwhile, in sharia insurance, premium and profit investment is claimed as the company's profit if the company has already accepted it financially. Every insurance customer will pay its premium which is a certain time according to the insurance company. According to Anwar, sharia insurance premium consists of two types, those are savings and tabarru'. Tabarru' is good charity or subscription, which is from customers' intention for helping each other if there are other customers in trouble[5], [6].

Prudential is one of the largest insurance companies in the world. Prudential was established in 1848 in London, England. It entered into Indonesia in 1995 then became a dominant insurance company in Indonesia. 
Seeing Indonesia which have $87 \%$ Muslim population of its total population, this is the largest market for Prudential. Thus in 2007, Prudential launched sharia insurance which is known as Prudential Shariah. Prudential Sharia can become a choice for every customer who needs the protection of life, health, and investment according to the Islamic sharia principle which is supervised by Dewan Shariah Nasional. The development of Prudential in Indonesia since its entrance has been experiencing a significant increase in 2012. In addition, it has reached 254.000 customers. In 2016, there are 2.400.000 customers with the total asset of IDR 64, 2 trillion, increased $13 \% *$, with the insurance premium income is IDR 26,5 trillion, increased $8 \% *$, and the claim payment is IDR 9,9 trillion, increased $14 *$ (including sharia) [7], [8].

Meanwhile, the number of active insurance policy on Prudential Sharia in 2016 is 510.000 with the total income from tabarru (fundraising) contribution is IDR 2, 2 trillion. In 2017, the total claim payment is IDR 12, 3 trillion; increased $24 \%$ from the previous year with the premium with the total premium income is IDR 6,8 trillion and the asset of IDR 81, 7 trillion. The contribution of premium income of Prudential Sharia in 2017 is IDR 3, 4 trillion with the total asset is IDR 9,9 trillion. "Prudential in Indonesia still becomes the dominant player through its sharia insurance business." The percentage of Prudential Sharia customers tends to increase significantly even before one decade in 2018. It even beats some of the other dominant players in Indonesia and still consistent with its existence as the top category of sharia insurance in Indonesia, according to Top Brand Award. Prudential Sharia Insurance until 2018 phase still becomes the number 1 insurance on the life and health insurance [9].

Based on data, it emphasizes the curiosity about Prudential Sharia Insurance 1) why this insurance is increasing so significantly and still able to defend its position as the best sharia insurance in Indonesia as the first top category? Becoming the best insurance company until the first phase of 2018 and being based on customers' preference, it emphasizes many questions towards Prudential Sharia Insurance itself; 2) Does the Prudential Sharia have the influence to the customer welfare; 3) What causes Prudential Sharia insurance to become the best choice in the society? [10], [11].

\section{METHOD}

This research was done by quantitative approach and primary data. The study area of this research is located in South Sulawesi for the prudential sharia customers. The number of the customer consists of 41.871. Purposive sampling is used for choosing the study area. Stratified random sampling is used in determining sample size from the customers. In this research, the researchers apply the standard of error in collecting sample such amount $10 \%$.
According to the data above, so the number of sample size that will be used in this research can be known by this following calculation;

$$
\begin{aligned}
& \text { Slovin Formula: } \\
& \begin{aligned}
\boldsymbol{n} & =\frac{41.871}{1+41.871(0,1)^{2}} \\
& =99,76 \Rightarrow 100
\end{aligned}
\end{aligned}
$$

Based on the purposive sampling by using Slovin formula above, researchers use 100 customers as respondents in South-Sulawesi for measuring customers' welfare, which ever was claimed. The primary data of research variables will be carried out by questionnaire. Then, the data will be analyzed with multiple linear regression.

Economic model defines the statistical relationship between variables in particular phenomena. This research uses multiple linear regression models below:

$Y=\beta 0+\beta 1 X 1+\beta 2 X 2+e$

Where;

$\boldsymbol{Y}=$ customer welfare

$\boldsymbol{\beta} \mathbf{0}=$ constant

$\boldsymbol{\beta} 1=$ prudential sharia regression coefficient

$\boldsymbol{\beta} 2=$ life protection regression coefficient

$\boldsymbol{X} \mathbf{1}=$ Prudential Sharia scale

$\boldsymbol{X} \mathbf{2}=$ life protection scale

$\boldsymbol{e}=$ error term

\section{RESULT}

The questionnaire that has distributed must be tested by using validity and reliability test.

\begin{tabular}{|c|c|c|c|c|}
\hline \multicolumn{5}{|c|}{ Anti-image Matrices } \\
\hline \multirow[b]{2}{*}{$\begin{array}{l}\text { Anti- } \\
\text { image }\end{array}$} & \multirow[b]{2}{*}{$\mathrm{X} 1$} & \multirow{2}{*}{$\begin{array}{l}\mathrm{X} 1 \\
.363\end{array}$} & \multirow{2}{*}{$\begin{array}{l}\mathrm{X} 2 \\
\quad-.155\end{array}$} & \multirow{2}{*}{$\begin{aligned} \text { X3 } & \\
& -.161\end{aligned}$} \\
\hline & & & & \\
\hline Covarianc & $\mathrm{X} 2$ & -.155 & .373 & -.154 \\
\hline $\mathrm{e}$ & $\mathrm{X} 3$ & -.161 & -.154 & .365 \\
\hline $\begin{array}{l}\text { Anti- } \\
\text { image }\end{array}$ & $\mathrm{X} 1$ & $.749^{\mathrm{a}}$ & -.420 & -.442 \\
\hline Correlatio & $\mathrm{X} 2$ & -.420 & $.758^{\mathrm{a}}$ & -.416 \\
\hline $\mathrm{n}$ & X3 & -.442 & -.416 & $.750^{\mathrm{a}}$ \\
\hline a. Measure & Samp & acy(MS & & \\
\hline
\end{tabular}

\section{Validity Test}

Table 1: Anti-image Matrices

Table 2: KMO and Bartlett's Test

\begin{tabular}{llr}
\hline Kaiser-Meyer-Olkin Measure of & .752 \\
Sampling Adequacy. & & \\
Bartlett's Test of & Approx. & 175.233 \\
Sphericity & Chi- & \\
& Square & 3 \\
& Df & .000 \\
\hline
\end{tabular}

The value of KMO is 0,752 it shows that the instrument is valid because it meets the standard which is $0,50(0,752>0,50)$. Anti-image correlation results the correlation is high for each item. 0,749 (X1), 0,758 (X2), $0,750(\mathrm{X} 3)$. 
Table 3: Reliability Test

\begin{tabular}{cc}
\hline \multicolumn{3}{c}{ Reliability Statistics } \\
Cronbach's Alpha & N of Items \\
.889 & \\
\hline
\end{tabular}

The instrument can be categorized as reliable if the coefficient Cronbach's Alpha is bigger or equal with 0,70. As a result above, Cronbach's Alpha is 0,889 so that it can be concluded that variable in this research is reliable.

Before the data is qualified, it needs to do classical assumption test, in which all of the tests must be passed.

The aim of normality test is to see whether the dependent and independent variables in the multiple linear regression models have normal distribution or not.

According to figure 1 , it shows that the data (dots) spread around the diagonal line following the path of the diagonal line. Therefore, the conclusion is the regression model fulfilling the normality assumption.

\section{Heteroscedasticity test:}

Heteroscedasticity refers to the circumstance in which the variability of a variable is unequal across the range of values of a second variable that predicts it. The aims of heteroscedasticity test are to identify the existence of deviation from the terms of classical assumption at the regression model. Where the regression model must be passed in terms zero heteroscedasticity.

Table 4. Heteroscedasticity Test

\begin{tabular}{|c|c|c|c|c|c|c|}
\hline \multicolumn{7}{|c|}{ Coefficients $^{\text {a }}$} \\
\hline & \multirow[t]{2}{*}{ Model } & \multicolumn{2}{|c|}{$\begin{array}{l}\text { Unstandardized } \\
\text { Coefficients }\end{array}$} & \multirow{2}{*}{$\begin{array}{c}\text { Standardized } \\
\text { Coefficients } \\
\text { Beta }\end{array}$} & \multirow[t]{2}{*}{$\mathrm{T}$} & \multirow[t]{2}{*}{ Sig. } \\
\hline & & B & $\begin{array}{l}\text { Std. } \\
\text { Error }\end{array}$ & & & \\
\hline \multirow{4}{*}{1} & (Constant) & & & & & \\
\hline & & 1.275 & 1.083 & & 1.178 & .242 \\
\hline & $\begin{array}{l}\text { Prudential } \\
\text { Syariah }\end{array}$ & .121 & .072 & .248 & 1.667 & .099 \\
\hline & $\begin{array}{l}\text { life } \\
\text { protection } \\
\text { scale }\end{array}$ & -.096 & .072 & -.199 & -1.333 & .186 \\
\hline & endent $\mathrm{V}$ & le: ABS & & & & \\
\hline
\end{tabular}

Based on table 4 and figure 2, it can be identified that the data spread randomly, and it does not form a pattern. It is concluded there is no heteroscedasticity in this model and it passes by heteroscedasticity test.

\section{Multicollinearity Test:}

Multicollinearity is a high degree of correlation (linear dependency) among several independent variables. According to (Nachrowi \& Usman, 2006), Multicollinearity can be indicated by pointing out the VIF value. If VIF value is greater than 10 , it shows a collinearity problem. For this model, it shows that both of variables are 2,215 so that VIF values is well below 10. Therefore, it is concluded that there is no

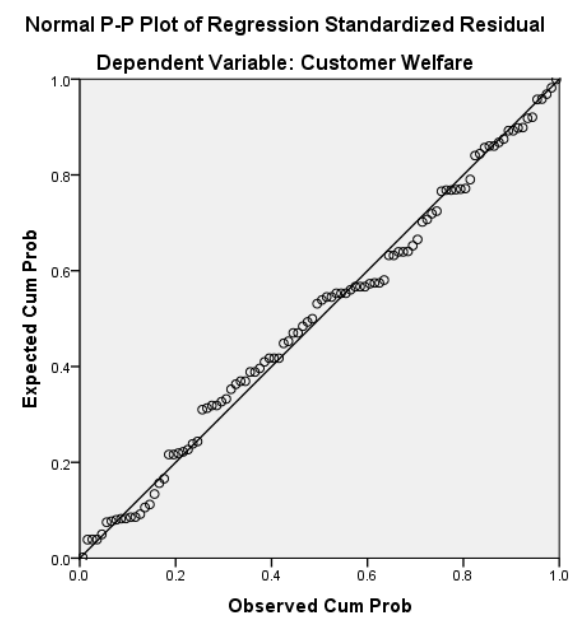

Figure 1. Normality Test

collinearity within the data in this model. Hence, it passes through the multicollinearity test.

\section{Multiple Regression Linear test}

Table 5. Multiple Regression Linear test

\begin{tabular}{lllll}
\hline \multicolumn{4}{c}{ Model Summary } \\
\hline Model & $\mathrm{R}$ & R Square & $\begin{array}{l}\text { Adj.R } \\
\text { Square }\end{array}$ & $\begin{array}{l}\text { Std. Error of the } \\
\text { estimate }\end{array}$ \\
\hline 1 & $.797^{\mathrm{a}}$ & .635 & .628 & 2.317 \\
\hline
\end{tabular}

a. Predictors: (Constant), Prudential Syariah, protection life scale

\section{Coefficient Determinant $\left(\mathbf{R}^{2}\right)$}

The great influence of Prudential shariah and life protection scale simultaneously to the customer welfare is showed by Adjusted R Square value as much 0,628, which means $62,8 \%$ customer welfare is influenced by Prudential Sharia and protection life scale.

Table 6. Regression Stimulant Test

\begin{tabular}{lllllll}
\hline \multicolumn{7}{c}{ Annova $^{\text {a }}$} \\
\hline \multirow{2}{*}{ Model } & $\begin{array}{l}\text { Sum of } \\
\text { Squares }\end{array}$ & Df & $\begin{array}{l}\text { Mean } \\
\text { Square }\end{array}$ & F & Sig. \\
\hline \multirow{2}{*}{1} & Regression & 906.445 & 2 & 453.222 & 84.414 & $.000^{\mathrm{b}}$ \\
\cline { 2 - 6 } & Residual & 520.795 & 97 & 5.369 & & \\
\cline { 2 - 6 } & Total & 1427.240 & 99 & & & \\
\hline
\end{tabular}

a. Dependent Variable: customer welfare

b. Predictors: (Constant), Prudential Syariah, protection life scale

\section{Regression Stimulant test (F-test)}

Based on above, the test results f-test as much as 84 , 414 with the probability 0,000. According to the requirement of F-test where the probability value $\leq 0,05$, Prudential sharia and life protection scale simultaneously can predict the changes of customer welfare.

Table 7. Regression Partial

\begin{tabular}{|c|c|c|c|c|c|}
\hline \multirow[t]{2}{*}{ Model } & \multicolumn{2}{|c|}{$\begin{array}{l}\text { Unstandardized } \\
\text { Coefficients }\end{array}$} & \multirow{2}{*}{$\begin{array}{l}\text { Standardized } \\
\text { Coefficients } \\
\text { Beta }\end{array}$} & \multirow[t]{2}{*}{$\mathrm{t}$} & \multirow[t]{2}{*}{ Sig. } \\
\hline & $\mathrm{B}$ & $\begin{array}{l}\text { Std. } \\
\text { Error }\end{array}$ & & & \\
\hline (Constant) & 16.382 & 1.737 & & 9.434 & .000 \\
\hline
\end{tabular}




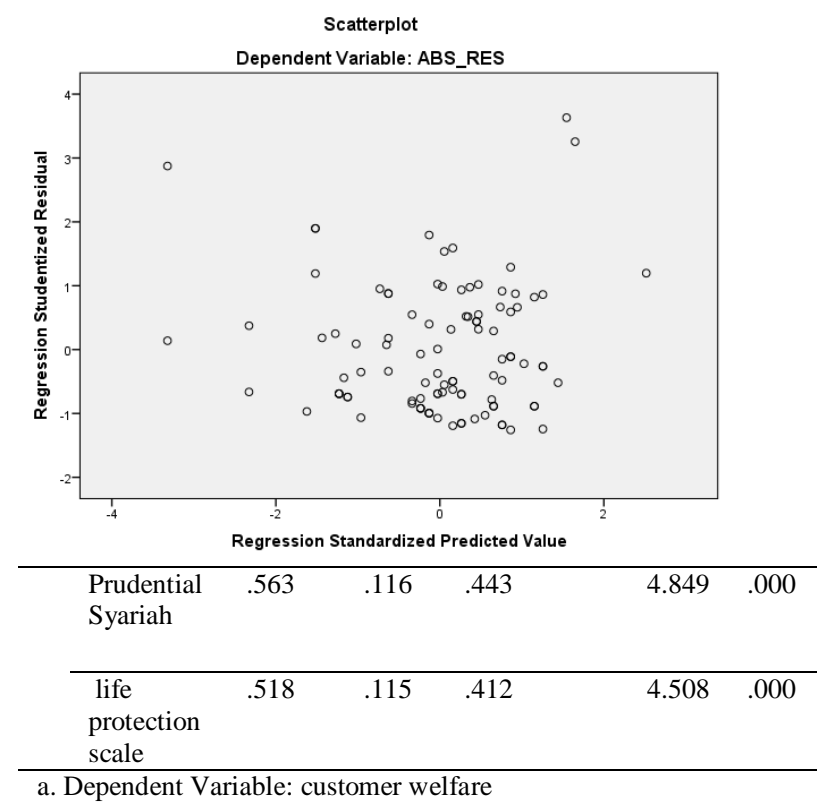

Figure 2. Heteroscedasticity Test

\section{Regression Partial (T-test) $Y=16,382+0,563 X_{1}+0,518 X_{2}+e$}

Prudential Sharia

According to the regression partial test, t-value as much 4,849 regression coefficient (beta) 0,563 with the probability $(\mathrm{p})=0,000$. The probability value $\leq 0,05$ can be concluded that Prudential Sharia has a positive and significant influence to the customers welfare.

Protection life scale

According to the regression partial test, the test results of t-value as much 4,508 regression coefficient (beta) 0,518 with probability $(\mathrm{p})=0,000$. Based on the data, the probability value $(\mathrm{p}) \leq 0,05$ can be concluded that life protection scale influences positively and significantly to the customers welfare.

\section{CONCLUSION}

This research analyzes the influence of sharia insurance towards customer welfare on the study case of Prudential Sharia in South Sulawesi with 100 respondents. Then, the result is tested using multiple linear regression, and shows the result of every independent variable. Prudential Sharia and life protection scale shows positive and significant impact on the dependent variable, particularly on customer welfare.

\section{REFERENCES}

[1] I. Syafrida, I. Aminah, and B. Waluyo, "Perbandingan Kinerja Instrumen Investasi Berbasis Syariah dengan Konvensional di Pasar Modal Indonesia," Al-Iqtishad J. Ilmu Ekon. Syariah, 2014.

[2] (REPUBLIK INDONESIA) RI, "Undang-Undang Republik Indonesia Nomor 23 Tahun 2002 Tentang Perlindungan Anak," Kementerian Luar Negeri Republik Indonesia, 2002. .

[3] AWALUDDIN, "PASAR MODAL SYARIAH : ANALISIS PENAWARAN EFEK SYARIAH DI BURSA EFEK INDONESIA," MAQDIS J. Kaji. Ekon. Islam, 2016.

[4] H. Sudarsono, "Dampak Krisis Keuangan Global terhadap Perbankan di Indonesia: Perbandingan antara Bank Konvensional dan Bank Syariah," La Riba J. Ekon. Islam, 2009.

[5] M. N. Yasin, "Progresifitas Formulasi Hukum Ekonomi Syariah Di Indonesia,” J. Jure, 2014.

[6] U. Riaz, B. Burton, and L. Monk, "Perceptions on Islamic banking in the $\mathrm{UK}$-Potentialities for empowerment, challenges and the role of scholars," Crit. Perspect. Account., 2017.

[7] Arther. G, "The Prudential Regulation of Banks," Econ. Rec., 1996.

[8] W. J. Kwon and L. Wolfrom, "Analytical tools for the insurance market and macro-prudential," OECD J. Financ. Mark. Trends, 2017.

[9] S. Abdullaev, "Prudential Oversight and Bank Deposit Insurance in Azerbaijan," Probl. Econ. Transit., 2005.

[10] S. K. Mathur, "Prudential Practices and Financial Stability: Some Conceptual Issues.," Geneva Pap. Risk Insur. - Issues Pract., 2002.

[11] T. M. Vaughan, "Financial Stability and Insurance Supervision: The Future of Prudential Supervision," in Geneva Papers on Risk and Insurance: Issues and Practice, 2004. 